\title{
27. Electoral Behaviour in the 2010 Australian Federal Election
}

\author{
Clive Bean and Ian McAllister
}

\begin{abstract}
All elections are unique, but the Australian federal election of 2010 was unusual for many reasons. It came in the wake of the unprecedented ousting of the Prime Minister who had led the Australian Labor Party (ALP) to a landslide victory, after 11 years in Opposition, at the previous election in 2007. In a move that to many would have been unthinkable, Kevin Rudd's increasing unpopularity within his own parliamentary party finally took its toll and in late June he was replaced with his deputy, Julia Gillard. Thus, the second unusual feature of the election was that it was contested by Australia's first female prime minister. The third unusual feature was that the election almost saw a first-term government, with a comfortable majority, defeated. Instead it resulted in a hung parliamentfor the first time since 1940 - and Labor scraped back into power as a minority government, supported by three Independents and the first member of the Australian Greens ever to be elected to the House of Representatives at a general election (previously, the Australian Greens' candidate Michael Organ was elected at a by-election in 2002). The Coalition Liberal and National Opposition parties themselves had a leader of only eight months' standing, Tony Abbott, whose ascension to the position had surprised more than a few. This was the context for an investigation of voting behaviour in the 2010 election.
\end{abstract}

The analysis in this chapter is based on the 2010 Australian Election Study (AES), conducted by Ian McAllister, Clive Bean, Rachel Gibson and Juliet Pietsch immediately following the federal election in August (McAllister et al. 2011). The data come from a national survey of political attitudes and behaviour using a self-completion questionnaire mailed to respondents just after the federal election. The survey was based on a systematic random sample of enrolled voters throughout Australia, stratified by State, drawn by the Australian Electoral Commission (AEC). After the initial mailing, the response rate was boosted by several follow-ups to non-respondents. The final response rate was 42 per cent. The data were weighted to reflect population parameters for gender, age, State and vote, giving a final sample size of 2061 . 


\section{Campaign Orientations}

The election was held less than two months after the replacement of Rudd with Gillard, with that event still clearly on people's minds. Nonetheless, public attention to the campaign was no greater than in the last election in 2007 and less in some respects, although it was greater for the most part than at the elections of 2001 and 2004 (Table 27.1). Fewer voters than in 2007 took a general interest in the election campaign (34 per cent compared with 40 per cent in 2007) or cared which party won (68 per cent compared with 76 per cent). Levels of attention to the campaign through the media, on the other hand, were almost identical to 2007, with 62 per cent, 77 per cent and 48 per cent saying they paid a good deal or some attention to the campaign in newspapers, television and radio respectively in 2010. Attention to the campaign via the Internet, however, almost doubled, with 29 per cent of the AES sample saying they paid attention to the campaign on the Internet in 2010 , compared with 16 per cent three years earlier.

Another question asking respondents whether they used the Internet to get news or information about the election showed a similar increase - the proportion rising from 20 per cent in 2007 to 36 per cent in 2010. The 2010 percentage is four times what it was back in 2001 and it would be surprising if we were not seeing such strong growth in the use of the Internet for political purposes. Table 27.1 also shows that some 47 per cent said they watched the televised leaders' debate, held early in the campaign-almost identical to 2007. Nearly four in 10 (37 per cent) judged Gillard to have won the debate against Tony Abbott, with only 22 per cent awarding the contest to the Leader of the Opposition.

Table 27.1 Engagement with the Election Campaign, 2001-10 (per cent)

\begin{tabular}{|c|c|c|c|c|}
\hline & 2001 & 2004 & 2007 & 2010 \\
\hline $\begin{array}{l}\text { Took 'a good deal' of interest in the election campaign } \\
\text { overall }\end{array}$ & 31 & 30 & 40 & 34 \\
\hline Cared 'a good deal' which party won & 65 & 72 & 76 & 68 \\
\hline \multicolumn{5}{|l|}{ Paid 'a good deal' or 'some' attention to the campaign: } \\
\hline in newspapers & 53 & 57 & 61 & 62 \\
\hline on television & 69 & 69 & 77 & 77 \\
\hline on radio & 43 & 44 & 50 & 48 \\
\hline on the Internet & - & - & 16 & 29 \\
\hline Used the Internet for election news or information & 9 & 12 & 20 & 36 \\
\hline Watched the televised leaders' debate & 40 & 35 & 46 & 47 \\
\hline $\begin{array}{l}\text { Thought Howard (2001-07)/ } \\
\text { Gillard performed better in the debate }\end{array}$ & 18 & 25 & 13 & 37 \\
\hline
\end{tabular}

Sources: Australian Election Study, $2001(\mathrm{n}=2010), 2004(\mathrm{n}=1769), 2007(\mathrm{n}=1873)$ and $2010(\mathrm{n}=2061)$. 
For some time there has been evidence that the numbers of voters leaving their final voting decision until into the election campaign is increasing in various democracies (McAllister 2002). In Australia, however, this trend, which developed pace in the 1990s (Bean and McAllister 2000), reversed in the early part of this century to the point where in 2007 it was back to the low levels of the 1980s (Bean and McAllister 2009). But the uncertain context of the 2010 election sent the proportion of late-deciding voters back up to near the levels of the late 1990s, with 47 per cent saying they definitely decided how they would vote during the election campaign (Table 27.2). At the same time, 29 per cent said they seriously thought of giving their first-preference vote in the House of Representatives to a different party from the one for which they eventually voted.

Table 27.2 Volatility, Stability and Partisanship, 2001-10 (per cent)

\begin{tabular}{|l|c|c|c|c|}
\hline & $\mathbf{2 0 0 1}$ & $\mathbf{2 0 0 4}$ & $\mathbf{2 0 0 7}$ & $\mathbf{2 0 1 0}$ \\
\hline Decided definitely how to vote during campaign period & 41 & 39 & 29 & 47 \\
\hline $\begin{array}{l}\text { Seriously thought of giving first preference to another } \\
\text { party in the House of Representatives during election } \\
\text { campaign }\end{array}$ & 29 & 25 & 23 & 29 \\
\hline Always voted for same party & 48 & 50 & 45 & 52 \\
\hline Identifier with one of the major parties & 77 & 77 & 77 & 78 \\
\hline Not a party identifier & 15 & 16 & 16 & 14 \\
\hline Very strong party identifier & 19 & 21 & 25 & 19 \\
\hline
\end{tabular}

Sources: Australian Election Study, $2001(\mathrm{n}=2010), 2004(\mathrm{n}=1769), 2007(\mathrm{n}=1873)$ and $2010(\mathrm{n}=2061)$.

Party identification, which declined somewhat in the late 1990s (Bean and McAllister 2000, 183), has been very steady since the beginning of the twentyfirst century. A little less than 80 per cent of the electorate now identifies with one of the major parties (78 per cent in 2010) and about one in six or seven claims not to be a party identifier at all (14 per cent in 2010). Given the volatile nature of the 2010 election, as reflected in the success of Independent candidates and minor parties and in the suboptimal outcome for the two major parties, it is perhaps a little surprising that party identification did not slip further in 2010. In continuing to exhibit relatively high levels of party identification, even in such circumstances, Australia stands apart from many other countries, where party loyalties have been in decline over the past few decades (Dalton and Wattenberg 2000; Webb et al. 2003; White and Davies 1998). On the other hand, the proportion of very strong identifiers has settled back to where it had been (19 per cent) after an increase in 2007 that now appears to have been an aberration rather than the beginning of a trend. 


\section{Socio-Demographics and the Vote}

While relationships between social structure and voting are now consistently weaker than they used to be (McAllister 2011), the extent to which demographics and social location align with support for different political parties nevertheless continues to warrant attention. With the first female prime minister contesting an Australian national election, gender is a variable of particular interest. The traditional association between gender and party, in which women voted more conservatively than men, has not been in evidence in Australia for some time (Bean and McAllister 2009). The evidence for 2010 suggests that having a woman leading the government might make a difference to how women vote, with 8 per cent more women giving their first-preference vote in the House of Representatives to the Labor Party than men, and 9 per cent more men voting Liberal-Nationals than women (Table 27.3). This, of course, represents a reversal of the traditional gender gap.

Table 27.3 Gender, Age, Region, Religion and Vote, 2010 (per cent)

\begin{tabular}{|c|c|c|c|c|c|}
\hline & Labor & Lib-Nats & Greens & Other & (n) \\
\hline \multicolumn{6}{|l|}{ Gender } \\
\hline Male & 36 & 50 & 12 & 2 & (976) \\
\hline Female & 44 & 41 & 13 & 2 & (977) \\
\hline \multicolumn{6}{|l|}{ Age group } \\
\hline Under 25 & 37 & 41 & 19 & 3 & (189) \\
\hline $25-44$ & 43 & 39 & 17 & 2 & (666) \\
\hline $45-64$ & 43 & 44 & 11 & 2 & (707) \\
\hline 65 and over & 33 & 61 & 4 & 2 & (391) \\
\hline \multicolumn{6}{|l|}{ Region } \\
\hline Rural & 35 & 51 & 11 & 3 & (434) \\
\hline Urban & 42 & 44 & 13 & 1 & (1502) \\
\hline \multicolumn{6}{|l|}{ Religious denomination } \\
\hline Catholic & 41 & 48 & 9 & 2 & (510) \\
\hline Anglican & 35 & 56 & 8 & 1 & (385) \\
\hline Uniting & 38 & 53 & 6 & 3 & $(220)$ \\
\hline Other & 38 & 47 & 13 & 2 & (297) \\
\hline No religion & 45 & 32 & 21 & 2 & (534) \\
\hline \multicolumn{6}{|l|}{ Church attendance } \\
\hline At least once a month & 34 & 54 & 8 & 4 & $(300)$ \\
\hline At least once a year & 41 & 50 & 8 & 1 & $(440)$ \\
\hline Less than once a year & 31 & 51 & 17 & 1 & (313) \\
\hline Never & 45 & 39 & 15 & 2 & (885) \\
\hline
\end{tabular}


Reminiscent of the 2004 election, in 2010, Labor fared badly with both young and old voters, despite the fact that the more usual pattern is for Labor to show a significant degree of appeal to younger voters (Bean 2007). The Greens, who usually attract good support from the young, appear to have been the main beneficiary again on this occasion, while the advantage enjoyed by the Coalition among voters aged sixty-five and over has grown quite large, with the Greens as well as Labor faring particularly poorly among this cohort.

The traditional urban-rural divide remained clearly in evidence in 2010, with the Coalition favoured in rural areas. With respect to religion, Protestant denominations preferred the Coalition, as usual, and those with no religion preferred Labor or the Greens. Catholics, however, although more favourable to Labor than Protestants, were more inclined to opt for the Coalition than Labor - a situation that, though unusual in Australian electoral history, has occurred before - in the elections of 1996 and 2004 (Bean 2000; Bean and McAllister 2005). For the other dimension of religion - church attendance - as we have come to expect, frequent attenders favoured the Coalition and non-attenders Labor (and the Greens), but in between the patterns lacked consistency.

Table 27.4 turns the focus to socioeconomic status variables. In terms of education, the Coalition appears to have done best among electors who have some post-school education but not at the university level, while the Greens did particularly well among the university qualified (with 20 per cent of such voters giving the Greens their first preference). In attracting the votes of the university educated in such large numbers, the Greens completely eliminated the advantage Labor has had over the Coalition among this group in recent elections (Bean and McAllister 2009).

Table 27.4 Education, Occupational Indicators and Vote, 2010 (per cent)

\begin{tabular}{|c|c|c|c|c|c|}
\hline & Labor & Lib-Nats & Greens & Other & (N) \\
\hline \multicolumn{6}{|l|}{ Education } \\
\hline No post-school qualification & 43 & 46 & 10 & 1 & (594) \\
\hline Non-degree qualifications & 39 & 49 & 9 & 2 & (785) \\
\hline University degree & 39 & 39 & 20 & 2 & $(541)$ \\
\hline \multicolumn{6}{|l|}{ Occupation } \\
\hline Manual & 46 & 42 & 10 & 2 & (549) \\
\hline Non-manual & 37 & 47 & 14 & 2 & (1199) \\
\hline \multicolumn{6}{|l|}{ Employment } \\
\hline Self-employed & 27 & 60 & 12 & 1 & (292) \\
\hline Government employee & 48 & 36 & 14 & 2 & (447) \\
\hline \multicolumn{6}{|l|}{ Trade union membership } \\
\hline Union member & 53 & 31 & 14 & 2 & (426) \\
\hline Not a union member & 36 & 50 & 13 & 2 & $(1412)$ \\
\hline
\end{tabular}


Table 27.4 also shows that the tendency in recent elections for the strength of occupational voting to be variable (Bean and McAllister 2009; McAllister 2011 ) continued in 2010. Once the rock of Australian electoral choice, class voting (as measured by the difference between the non-manual vote for Labor and the manual vote for Labor) has dipped below 10 per cent at some recent elections, but has reached as high as (a still modest) 17 per cent at others (Bean and McAllister 2009). In 2007 it was 15 per cent. In 2010, class voting was down again, at 9 per cent, continuing the trend for it to be up at one election and down at the next.

The last two sections of Table 27.4 show that employment sector and trade union membership continue to shape the vote. For instance, 48 per cent of government employees reported voting Labor, compared with 27 per cent of the self-employed, while 53 per cent of union members voted Labor compared with 36 per cent of voters who were not members of a trade union.

\section{Leader Evaluations}

Party leader evaluations play a consistently significant role in Australian elections, although, despite some speculation to the contrary, there is little indication that their impact is on the rise (Senior and van Onselen 2008). The impact of leadership varies in different circumstances. In 2010, the presence of a female prime minister, as well as the fact that both major-party leaders were relatively new in their roles, generated additional attention for the leadership factor. Compared with past elections, in 2010, no leader rated highly. Table 27.5 has the relevant data. Gillard herself received a mean rating of 4.9 (on a scale where zero represents a strong dislike, five represents a neutral position and 10 represents a strong liking for the leader). While not a strong rating, it was considerably higher than that for Abbott, whose mean score was only 4.3. Ironically - but probably of no surprise to many - the politician with the highest rating was deposed leader Rudd, who slightly outdid his successor by recording a mean rating of five. A question in the AES, specifically included to gauge voter reactions to the overthrow of Rudd, found that virtually threequarters of the electorate (74 per cent) disapproved of the way the leadership change was handled by the Labor Party. 
Table 27.5 Ratings of Leaders and Parties, 2010 (means on 0-10 scale)

\begin{tabular}{|l|c|c|c|c|c|}
\hline Leader & Mean & Std dev. & Party & Mean & Std dev. \\
\hline Julia Gillard & 4.9 & 3.1 & Labor & 5.1 & 3.0 \\
\hline Tony Abbott & 4.3 & 3.1 & Liberal & 5.1 & 3.3 \\
\hline Warren Truss & 4.1 & 2.2 & Nationals & 4.3 & 2.7 \\
\hline Bob Brown & 4.1 & 2.9 & Greens & 4.2 & 3.0 \\
\hline Wayne Swan & 4.0 & 2.5 & & & \\
\hline Kevin Rudd & 5.0 & 3.1 & & & \\
\hline
\end{tabular}

Source: Australian Election Study, $2010(\mathrm{n}=2061)$.

The Labor and Liberal parties as such were more popular with the public than the party leaders - both recording mean ratings of 5.1. The leaders of the smaller parties - Warren Truss of The Nationals and Bob Brown of the Greens - were also marginally less popular than the parties they led.

The data in Table 27.6 also show that gender again played a role in leadership evaluations (see also Denemark et al. 2011). Women rated Gillard considerably higher and Abbott somewhat lower than men. Viewing the same information from a different perspective, we see that men rated Gillard and Abbott equally (both at 4.5), while there was a very large difference among women in favour of Gillard, who received a mean rating of 5.3 among women compared with Abbott's four. Two other patterns stand out in Table 27.6. Abbott was the only politician of the six included in the survey who was rated more favourably by men than by women. As well as Gillard, Truss, Brown, Wayne Swan and Rudd all had higher scores among women than among men. As a result, at least in the election of 2010, women voters emerged as having a considerably more positive view of politicians overall than men. The mean rating of the six leaders by women was 4.6. The mean rating by men was 4 .3. And the final point of interest in Table 27.6 is that Rudd was almost as popular among women as Gillard.

Table 27.6 Ratings of Party Leaders by Gender, 2010 (means on 0-10 scale)

\begin{tabular}{|l|c|c|c|c|}
\hline Leader & Men mean & Std dev. & Women mean & Std dev. \\
\hline Julia Gillard & 4.5 & 3.1 & 5.3 & 3.0 \\
\hline Tony Abbott & 4.5 & 3.0 & 4.0 & 3.1 \\
\hline Warren Truss & 4.0 & 2.1 & 4.2 & 1.9 \\
\hline Bob Brown & 3.8 & 3.0 & 4.5 & 2.8 \\
\hline Wayne Swan & 3.9 & 2.6 & 4.1 & 2.4 \\
\hline Kevin Rudd & 4.8 & 3.1 & 5.2 & 3.0 \\
\hline
\end{tabular}

Source: Australian Election Study, $2010(\mathrm{n}=2061)$. 
Gillard's advantage over Abbott remained when individual leadership qualities were examined. Respondents were asked how well a list of leadership qualities described each of the two major-party leaders. Gillard outscored Abbott on all nine items. Gillard's best quality was deemed to be her intelligence (87 per cent of AES respondents judging this quality to describe her extremely or quite well), followed by her being seen as knowledgeable. She also was rated highly for being competent and sensible, while at the other end of the scale she was not seen as trustworthy or inspiring. Interestingly, Abbott's image largely shadowed Gillard's - at both ends of the scale - but always with lower proportions of voters rating him well on the particular trait and in some cases much lower. The only instances in which the difference between Abbott and Gillard was minimal occurred with respect to traits on which both were judged poorly: trustworthiness, honesty and, to a lesser extent, strength of leadership.

Table 27.7 Leadership Qualities Ascribed to Julia Gillard and Tony Abbott, 2010 (percentage saying quality describes leader extremely well or quite well)

\begin{tabular}{|l|c|c|}
\hline Quality & Julia Gillard & Tony Abbott \\
\hline Intelligent & 87 & 69 \\
\hline Compassionate & 58 & 44 \\
\hline Competent & 70 & 54 \\
\hline Sensible & 70 & 48 \\
\hline Provides strong leadership & 58 & 52 \\
\hline Honest & 48 & 43 \\
\hline Knowledgeable & 78 & 57 \\
\hline Inspiring & 42 & 28 \\
\hline Trustworthy & 40 & 36 \\
\hline
\end{tabular}

Source: Australian Election Study, 2010 (n = 2061).

\section{Issues}

The policy issues debated in election campaigns involve a mix of the perennial and the topical. Recent research on Australian elections has pointed to the importance of issues for voting choice and election outcomes (Goot and Watson 2007) in contrast with the conventional wisdom that election campaigns and therefore election issues make very little difference (see, for example, Aitkin 1982). The 2010 AES asked respondents to rate 12 issues in terms of their importance (Table 27.8). Health is always on the agenda in modern elections. But irrespective of how prominent they are in the parties' campaigns, the issues of health and Medicare are invariably the issues of most concern to voters. And so it was yet again in 2010, with 73 per cent of voters saying the issue was 
extremely important - clearly ahead of any other issue. Next came management of the economy (70 per cent rated it extremely important) and then education (with 61 per cent seeing it as extremely important).

Table 27.8 Importance of Election Issues (percentage describing issue as extremely important) and Party Differential (percentage saying Labor closer on issue minus percentage saying Liberal-Nationals closer), 2010

\begin{tabular}{|c|c|c|c|c|c|c|}
\hline \multicolumn{7}{|c|}{ Importance } \\
\hline Issue & $\begin{array}{c}\text { All } \\
\text { voters }\end{array}$ & $\begin{array}{l}\text { Labor } \\
\text { voters }\end{array}$ & $\begin{array}{l}\text { Lib-Nats } \\
\text { voters }\end{array}$ & $\begin{array}{l}\text { Greens } \\
\text { voters }\end{array}$ & $\begin{array}{l}\text { Other } \\
\text { voters }\end{array}$ & $\begin{array}{c}\text { Party } \\
\text { differential }\end{array}$ \\
\hline Global warming & 30 & 40 & 16 & 55 & 33 & +11 \\
\hline Taxation & 40 & 37 & 46 & 34 & 40 & -6 \\
\hline Education & 61 & 67 & 55 & 67 & 63 & +17 \\
\hline Unemployment & 40 & 45 & 38 & 34 & 43 & +7 \\
\hline The environment & 41 & 48 & 28 & 72 & 43 & +13 \\
\hline Interest rates & 43 & 43 & 48 & 31 & 42 & -9 \\
\hline Industrial relations & 28 & 35 & 22 & 29 & 31 & +9 \\
\hline Health and Medicare & 73 & 78 & 70 & 71 & 74 & +11 \\
\hline $\begin{array}{l}\text { Refugees and asylum- } \\
\text { seekers }\end{array}$ & 37 & 32 & 42 & 37 & 46 & -17 \\
\hline The resources tax & 30 & 25 & 37 & 22 & 38 & -5 \\
\hline Population policy & 32 & 30 & 36 & 26 & 37 & -5 \\
\hline $\begin{array}{l}\text { Management of the } \\
\text { economy }\end{array}$ & 70 & 68 & 80 & 51 & 74 & -9 \\
\hline
\end{tabular}

Source: Australian Election Study, $2010(\mathrm{n}=2061)$.

No other issue had as many as 50 per cent calling it extremely important. In fact the drop-off to the next issue was huge-nearly 20 per cent. Interest rates (43 per cent), the environment (41 per cent), taxation and unemployment (both 40 per cent) were next, but a very long way behind. Two topical issues in the campaign, the mining resources tax and population policy, rated only 30 per cent and 32 per cent respectively. Likewise, global warming was seen as extremely important by only 30 per cent of the sample and industrial relations rated least important of all with 28 per cent.

Of the three top issues, the far right-hand column of Table 27.8 shows that Labor had an advantage on health and education, in that voters reported that Labor's policies on these issues came closer than the Coalition's policies to their own views, while the Coalition had an advantage on management of the economy. Labor's advantage on education in particular was quite large, with 17 per cent more voters saying the Labor Party was closer to them on this issue than the Coalition. 
The middle columns of Table 27.8 demonstrate that the concerns of Labor voters largely mirrored those of the electorate as a whole. Labor voters showed particular concern about health and education. The concerns of Liberal-Nationals voters represented greater extremes, with 80 per cent citing management of the economy as extremely important, on the one hand, and only 16 per cent showing such concern about global warming, on the other. Coalition voters also displayed a relative lack of concern about the environment in general and considerably more concern than Labor voters about the resources tax. As would be expected, the environment was the greatest concern for Greens voters, albeit closely followed by health and with education also not far behind. Greens voters showed a comparative lack of concern about management of the economy, but were much more concerned than others about global warming.

\section{Explaining the Vote}

But how much if at all did these issues and other factors matter for the decision by individual voters to give their first-preference votes to one party over another? To round out the analysis, we look collectively at the key variables we have been considering above to estimate their independent impact on the vote in the 2010 election. This is achieved through the application of multivariate analysis that estimates the net effect of each factor on the vote while controlling for all the others. The analysis includes each of the socio-demographic variables examined earlier in the chapter, the party leader ratings and the campaign issues, plus party identification. For ease of presentation, only the variables whose effects are statistically significant are shown in Table 27.9. Methodological details are provided in Appendix 25.1.

Table 27.9 Multivariate Analysis of Significant Influences on Voting Behaviour, 2010

\begin{tabular}{|l|c|c|}
\hline & $\begin{array}{c}\text { Non-standardised } \\
\text { regression coefficient }\end{array}$ & $\begin{array}{c}\text { Standardised } \\
\text { regression coefficient }\end{array}$ \\
\hline Gender (male) & 0.03 & 0.03 \\
\hline Education (university degree) & 0.03 & 0.03 \\
\hline Religious denomination (Catholic) & 0.04 & 0.04 \\
\hline Region (rural) & 0.03 & 0.03 \\
\hline Party identification & 0.55 & 0.52 \\
\hline Julia Gillard & -0.24 & -0.16 \\
\hline Tony Abbott & 0.15 & 0.10 \\
\hline Education & 0.08 & 0.06 \\
\hline Management of the economy & 0.13 & 0.10 \\
\hline
\end{tabular}

Note: R-squared $=0.74$. Entries in the table are statistically significant at $\mathrm{p}<0.05$ or better. Further methodological details can be found in Appendix 25.1.

Source: Australian Election Study, 2010 (n = 2061). 
Table 27.9 shows that four socio-demographic variables-gender, education, religious denomination and region of residence-had statistically significant effects on the vote in 2010, albeit of very modest size. With all other factors in the model taken into account, males, the university educated, Catholics and rural residents all showed a greater inclination to vote Liberal-Nationals rather than Labor compared with females, those without a university degree, Protestants (the reference category for religious denomination in the multivariate analysis) and urban residents. For gender and religion, these results represent the reverse of the traditional associations between these variables and the vote (McAllister 2011), and in the latter case it means that Labor can no longer claim to always be the party that attracts the Catholic vote.

It remains important to emphasise, however, the small size of all these socialstructural effects, particularly in contrast with party identification, which as usual had far and away the largest effect. The non-standardised regression coefficient shows that Liberal-Nationals identifiers were 55 per cent more likely to vote for the Coalition parties than Labor identifiers after all the other variables were taken into account.

Though small by comparison, leadership, too, had a significant impact on voting behaviour in 2010 and larger than at some recent elections (Bean and McAllister 2009; Senior and van Onselen 2008). Voters who strongly liked Gillard were 24 per cent more likely to vote Labor rather than Liberal-Nationals compared with voters who strongly disliked her (the negative sign in front of the coefficient in Table 27.9 simply indicates that positive sentiment towards Gillard was associated with a preference for Labor). By the same token, voters who strongly liked Abbott were 15 per cent more likely to vote Liberal-Nationals than those who strongly disliked him. Interestingly, there was no effect for the man who had been prime minister until less than two months before the election: Kevin Rudd.

Of the 12 issues included in the analysis, only two had statistically significant effects on the 2010 vote. Not surprisingly, given the focus on economic management during the global financial crisis over the two years leading up to the election, management of the economy was the strongest issue, with those who rated it as extremely important and were closer to the Coalition on the issue some 13 per cent more likely to vote Liberal-Nationals than Labor compared with those who rated economic management as extremely important and were closer to Labor on the issue. Education, which has become more prominent as an issue in recent times (Bean and McAllister 2009; McAllister 2011), was the other significant issue, although its effect was more modest. Issues such as health and taxation, which have consistently affected voting behaviour over the past 
two decades (Bean and McAllister 2009), did not reach statistical significance on this occasion. And no other issues featured, including the topical issues of population policy and taxing of the mining industry.

But what did the influence of the two leaders and the two significant issues on individual voting choice mean for the outcome of the election? We can make such calculations by combining estimates of their effects on individual voting behaviour with the extent of bias inherent in each variable towards one major party or the other. The technicalities of the calculations are detailed in Appendix 25.1. We have already seen in the earlier parts of the chapter, for instance, that the Coalition had an advantage among the electorate on management of the economy, while Labor had an advantage on education, and that Gillard was more popular (or, to be strictly correct, less unpopular) than Abbott.

By combining the effect (the regression coefficient) and the bias towards Labor or the Coalition (derived from the mean of the variable), we are able to estimate the net impact of each variable on the balance of the party vote. These calculations show that, ironically, each of the party leaders conferred a benefit, not on their own party, but on the rival party. In Gillard's case, it was very small (about 0.2 per cent), while for Abbott it was more than 1 per cent, reflecting his substantially greater unpopularity. Combining the two, we arrive at a net leadership effect of 0.9 per cent in favour of the Labor Party.

The two significant issues, on the other hand, virtually cancelled one another out. Management of the economy produced a net effect of 0.7 per cent to the Coalition, while education produced a net effect of 0.6 per cent to Labor, giving the barest advantage of 0.1 per cent to the Liberal-National parties for the two issues together. Subtracting this from the 0.9 per cent leadership effect, we get an overall effect for leaders and issues of 0.8 per cent in favour of Labor. While this advantage might seem slim, its significance is seen when we consider that in the final vote count in the 2010 election the Labor Party edged out the Coalition by an extremely narrow margin of 50.1 per cent to 49.9 per cent in the twoparty preferred vote.

Thus, in the end, amidst such a closely fought election, the leadership factor was crucial. Both major parties approached the election with leaders who were relatively inexperienced, untried and who lacked popularity within the electorate. But Abbott's greater unpopularity meant that the toll was higher for the Coalition than for Labor. All other things being equal, the analysis in this chapter suggests that had the Coalition gone to the 2010 Australian federal election with a leader who was viewed more favourably across the electorate, the outcome probably would have been a narrow victory for the Liberals and Nationals. 


\section{References}

Aitkin, Don. 1982. Stability and Change in Australian Politics. [Second edn]. Canberra: Australian National University Press.

Bean, Clive. 2000. 'Who now votes Labor?'. In John Warhurst and Andrew Parkin (eds), The Machine: Labor confronts the future. Sydney: Allen \& Unwin, 73-88.

Bean, Clive. 2007. 'Young people's voting patterns'. In Lawrence J. Saha, Murray Print and Kathy Edwards (eds), Youth and Political Participation. Rotterdam: Sense Publishers, 33-50.

Bean, Clive and McAllister, Ian. 2000. 'Voting behaviour'. In Marian Simms and John Warhurst (eds), Howard's Agenda: The 1998 Australian election. Brisbane: University of Queensland Press, 174-192.

Bean, Clive and McAllister, Ian. 2005. 'Voting behaviour: not an election of interest (rates)'. In Marian Simms and John Warhurst (eds), Mortgage Nation: The 2004 Australian election. Perth: API Network, 319-334.

Bean, Clive and McAllister, Ian. 2009. 'The Australian election survey: the tale of the rabbit-less hat. Voting behaviour in 2007'. Australian Cultural History 27: 205-18.

Dalton, Russell J. and Wattenberg, Martin P. (eds). 2000. Parties without Partisans: Political change in advanced industrial democracies. Oxford: Oxford University Press.

Denemark, David, Ward, Ian and Bean, Clive. 2011. Gender and leader effects in the 2010 Australian election. Paper prepared for presentation at the International Political Science Association Conference: What Ever Happened to North-South?, 16-19 February, São Paulo, Brazil.

Goot, Murray and Watson, Ian. 2007. 'Explaining Howard's success: social structure, issue agendas and party support, 1993-2004'. Australian Journal of Political Science 42: 253-76.

McAllister, Ian. 2002. 'Calculating or capricious? The new politics of late deciding voters'. In D. M. Farrell and R. Schmitt-Beck (eds), Do Political Campaigns Matter? Campaign effects in elections and referendums. London and New York: Routledge, 22-40.

McAllister, Ian. 2011. The Australian Voter: Fifty years of change. Sydney: UNSW Press. 
McAllister, Ian, Bean, Clive, Pietsch, Juliet and Gibson, Rachel. 2011. Australian Election Study, 2010: Codebook. Canberra: Australian Social Science Data Archive, The Australian National University.

Senior, Philip and van Onselen, Peter. 2008. 'Re-examining leader effects: have leader effects grown in Australian federal elections, 1990-2004?'. Australian Journal of Political Science 43: 225-242.

Webb, Paul, Farrell, David and Holliday, Ian (eds). 2003. Political Parties at the Millennium: Adaptation and decline in democratic societies. Oxford: Oxford University Press.

White, John Kenneth and Davies, Philip John (eds). 1998. Political Parties and the Collapse of the Old Orders. New York: State University of New York Press.

\section{Appendix}

The results shown in Table 27.9 are based on ordinary least squares multiple regression with pair-wise deletion of missing data. The dependent variable - firstpreference vote for the House of Representatives in the 2010 federal election - is scored 0 for Labor, 0.5 for minor parties and Independent candidates and 1 for Liberal-Nationals. Similarly, party identification is scored 0 for Labor, 0.5 for minor parties or no party identification and 1 for Liberal-Nationals. Apart from age, scored in years, all other independent variables are either 0-1 dummy variables or scaled to run from a low score of 0 to a high score of one.

The issue variables are derived from a combination of the importance ratings and the party closer to the respondent, so that at one end of the scale those who rated the issue as extremely important and felt closer to the Labor Party on the issue are scored 0 and at the other end those who rated the issue as extremely important and felt closer to the Coalition parties on the issue are scored one.

The calculations for the effects of the leaders on the balance of the party vote involve taking the difference between the neutral point of 0.5 on the $0-1$ leadership rating scale and the mean score for each leader and multiplying that by the non-standardised regression coefficient for the leader. This is perhaps the best of several defensible ways of calculating leadership effects on the balance of the party vote (Senior and van Onselen 2008:233-6). So for Gillard, the calculation was $0.49-0.5=-0.01 \mathrm{x}-0.24=0.2$ per cent to the Coalition. For Abbott, the calculation was $0.43-0.5=-0.07 \times 0.15=1.1$ per cent to Labor. These two results are then added together to arrive at the net leadership impact on the vote of 0.9 per cent to Labor. 
Similarly, the calculation for the impact of each significant issue on the party balance involves subtracting the neutral point on the $0-1$ scale of 0.5 from the mean of each variable and multiplying that difference by the non-standardised regression coefficient for the variable. For education, the difference score was -0.08 (and the regression coefficient 0.08 ) and for management of the economy the difference was 0.05 (and the regression coefficient 0.13). 